\title{
EFEKTIVITAS PEMBELAJARAN PEMAKNAAN PADA PELAJARAN IPA TERHADAP CHARACTER BUILDING SISWA MTSN TERATE PANDIAN SUMENEP
}

\author{
Al Qari'ah ${ }^{1}$, Habibi $^{2}$, Rini Yudiati ${ }^{3}$ \\ Universitas Wiraraja Sumenep \\ email: qori.diraz@gmail.com ${ }^{1}$
}

\begin{abstract}
ABSTRAK
Kemorosotan akhlak dan moral siswa perlu segera mendapatkan penanganan serius dari lembaga pendidikan yang ikut bertanggung jawab memberi pendidikan dengan proses dan model pembelajaran yang ditawarkan, salah satunya yaitu penerapan pembelajaran pemaknaan. Tujuan penelitian ini adalah untuk mengetahui keterlaksanaan pembelajaran pemaknaan dan perbedaan character building siswa pada pembelajaran IPA di kelas eksperimen dan kontrol sehingga dapat dijadikan landasan sebagai gambaran efektivitas pembelajaran pemaknaan terhadap character building siswa pada pelajaran IPA. Jenis penelitian yang digunakan yaitu deskriptif kuantitatif dengan teknik analisis data yaitu menggunakan statistik deskriptif dan uji $t$ independen. Hasil penelitian didapatkan pelaksanaan pembelajaran pemaknaan mencapai $81 \%$. Character building siswa kelas yang mengikuti pembelajaran pemaknaan dengan non-pemaknaan terdapat perbedaan sebesar 6,34 (Output uji T). Karakter siswa mengalami peningkatan pada karakter sosial, sedangkan karakter pribadi cenderung menurun. Karakter tanggung jawab, disiplin, dan demokratis memiliki peningkatan yang terendah.
\end{abstract}

Kata Kunci: Character building, pemaknaan, pembelajaran IPA

\section{PENDAHULUAN}

Fenomena kriminalitas yang dilakukan antar pelajar menimbulkan tanda tanya besar akan realisasi UndangUndang No. 20 tahun 2003 tentang Sisdiknas pada bab II pasal 3 yang menjelaskan bahwa fungsi Pendidikan Nasional adalah mengembangkan kemampuan dan membentuk watak serta peradaban bangsa yang bermartabat dalam rangka mencerdaskan kehidupan bangsa ternyata berbanding terbalik dengan kenyataan yang ada (Samani, 2012:26). Sebuah ironi bagi Indonesia yang selalu memborong medali dalam setiap kompetisi olimpiade sains internasional, namun di sisi lain kasus siswa cacat moral seperti siswa married by accident, kasus narkoba, mencontek, bersikap malas, dan sejenisnya semakin marak terjadi.

Kondisi ini sangat mengkhawatirkan bagi bangsa Indonesia, terutama dalam dunia pendidikan yang mengemban tugas penting untuk memulihkan moral anak didik yang semakin memburuk. Setidaknya fakta ini tidak boleh diabaikan karena kita tidak ingin anak bangsa kita kelak menjadi manusia yang amoral sebagaimana saat ini sering kita lihat di TV yang mempertonton-kan berita seperti pencurian, pemerkosaan, dan penculikan tidak hanya dilakukan oleh orang dewasa, tetapi juga anak usia belasan.

Melihat kondisi sekarang dan akan datang, ketersediaan sumber daya manusia yang berkarakter merupakan kebutuhan yang sangat vital. Kemorosotan akhlak dan moral perlu segera mendapat penanganan serius, baik oleh orang tua, guru, maupun lembaga pendidikan. Sebenarnya menambah pelajaran khusus di dalam kurikulum untuk mempelajari budi pekerti dan sikap positif tidak menyelesaikan masalah yang 
kita hadapi saat ini, akan tetapi pemecahan tersebut dapat dilakukan lewat pembelajaran itu sendiri. Salah satu alternatifnya pembelajaran pemaknaan.

Model pembelajaran reflektif (pemaknaan) diarahkan pada pemahaman terhadap makna dan nilai di balik suatu fakta, fenomena, informasi, atau benda yang menjadi bahan ajar dalam suatu mata pelajaran (Kesuma, dkk., 2011:121). Model pembelajaran pemaknaan mengajak anak untuk berefleksi, berimajinasi, berkomunikasi, dan tidak hanya dikenalkan pada materi secara eksplisit, akan tetapi belajar menjadi sesuai dengan makna atau nilai moral dibalik materi yang diajarkan. Pembelajaran yang diterapkan tidak hanya berlangsung menyampaikan materi, siswa mencatat, dan selesai, namun ciri inovasi dari model pembelajaran ini yang membedakan dengan model pembelajaran lainnya adalah adanya sintaks pemaknaan dari gejala atau peristiwa yang terdapat dalam substansi materi pelajaran dikaitkan dengan aspek-aspek budi pekerti, normanorma yang harus ditaati. Selain itu, pemaknaan dapat menggunakan gejala dan temuan dari siswa untuk menanamkan prinsip kebaikan, moral, dan akhlakul karimah. Contohnya guru memaknai konsep getaran. Setiap benda memiliki frekuensi alamiah yang mengakibatkan dua bandul yang sama (misalnya) digantungkan pada seutas tali yang panjangnya berbeda, maka akan menghasilkan frekuensi yang berbeda. Sebaliknya apabila sama, maka dapat mengakibatkan ikut bergetarnya bandul lain yang terpengaruh dan hal tersebut akan menguatkan simpangan. Hal ini dapat dianalogikan pada kehidupan kita, bahwa derap langkah yang serempak akan dapat merobohkan penghalang jalan kita menuju hal yang lebih baik, dalam artian misalnya saat melakukan kegiatan kerjasama/kelompok masing-masing anggota harus cekatan dalam melakukan tugas yang sudah dibagi-bagi sehingga kerjasama tersebut akan semakin kuat/solid.

Sintaks pembelajaran pemaknaan yang diterapkan dalam pembelajaran IPA di kelas adalah sebagai berikut.

1. Mengorientasikan Siswa terhadap Permasalahan

Sintaks ini merupakan langkah yang paling penting, karena akan dilakukan kegiatan yang membawa siswa pada masalah yang akan dipecahkan dalam proses pembelajaran. Tahapan ini berfungsi untuk menyiapkan dan menarik perhatian siswa. Tahapan ini dilakukan melalui cerita, demonstrasi, menyajikan fenomena alam, atau menggunakan konflik kognitif yang dimiliki siswa.

2. Merancang Proses Pemecahan Masalah

Tahapan ini dilakukan dengan tanya jawab atau diskusi yang bertujuan menemukan cara terbaik yang dapat dilakukan untuk memecahkan masalah.

3. Membimbing Penyelidikan

Tahapan ini guru memberikan bimbingan kepada siswa baik secara individu maupun kelompok untuk melakukan rencana yang telah disepakati, sehingga mereka dapat menemukan jawaban masalah atau pertanyaannya. Hasil kegiatan ini adalah data yang nantinya diolah untuk mendapatkan temuan yang merupakan jawaban masalah.

4. Mengkomunikasikan Hasil

Siswa diminta untuk mengkomunikasikan temuannya kepada siswa lain. Tahapan ini dapat dilaksanakan dalam bentuk diskusi kelas, presentasi kelas, atau menyusun laporan kegiatan. Inti dari tahapan ini adalah siswa lain dapat memperoleh informasi mengenai apa yang ditemukan oleh siswa dan dapat berkontribusi untuk menyempurnakan atau mengkritisi hasil kerja kelompok yang lain. 
5. Negosiasi dan Konfirmasi

Pada tahapan ini guru memberikan balikan terhadap apa-apa yang telah disampaikan oleh siswa pada tahapan sebelumnya. Balikan yang diberikan dapat merupakan penguatan, pembetulan, atau penyempurnaan informasi yang disajikan oleh siswa atau menambah informasi yang kurang. Dengan demikian diharapkan siswa nantinya memiliki informasi yang lengkap mengenai topik bahasan pada hari tersebut.

6. Pemaknaan

Ciri inovasi dari model ini adalah adanya sintaks pemaknaan dari gejala atau peristiwa yang terdapat dalam substansi materi pelajaran dikaitkan dengan aspek-aspek budi pekerti, norma-norma yang harus ditaati. Selain itu, pemaknaan dapat menggunakan gejala dan temuan dari siswa untuk menanamkan prinsip kebaikan, moral, dan akhlakul karimah.

7. Evaluasi dan Refleksi

Tahap ini bertujuan untuk mengetahui seberapa jauh siswa telah mencapai tujuan yang tela direncanakan, memperkuat retensi siswa, menemukan hal-hal yang sudah baik yang perlu dipertahankan atau menemukan hal-hal yang masih perlu ditingkatkan. Evaluasi dapat diberikan dengan test lisan, tertulis, unjuk kerja ataupun penugasan seperti menceritakan apa yang telah dipelajari kepada orangtuanya. Sedangkan refleksi dilakukan melalui diskusi. Setiap siswa diminta idenya mengenai hal-hal apa yang sudah baik dan hal apa yang belum baik.

Berdasarkan sintaks pembelajaran pemaknaan tersebut, maka pengembangan karakter (character building) siswa dinilai berdasarkan aktivitas yang berlangsung didalamnya dengan guru sebagai fasilitator dalam memaknai konsep pembelajaran IPA. Hal ini dikuatkan dengan pendapat Sardiman (2011:28) yang menyatakan bahwa interaksi belajar mengajar tidak akan lepas dari proses belajar perilaku dengan orang lain atau sosialisasi. Sebagian besar sosialisasi berlangsung lewat pemodelan. Sedangkan Ilmu Pengetahuan Alam (IPA) memiliki banyak fenomena atau gejala menarik yang berpotensi menjadi model pembentukan karakter, sikap positif, dan akhlakul karimah. Alam menyediakan model yang dapat ditiru oleh siswa asalkan guru membantu siswa untuk menangkap makna dan melakukan internalisasi terhadap gejala tersebut, kemudian dikaitkan dengan norma kebaikan dalam kehidupan sehari-hari. Oleh karena itu, model pembelajaran pemaknaan efektif penerapannya pada pembelajaran IPA yang dikembangkan untuk siswa SMP.

Hasil pencapaian model pembelajaran pemaknaan tidak dapat diartikan hanya pada ranah afektif saja, akan tetapi Ibrahim (2008:20) menegaskan bahwa implementasi model ini nantinya dapat mengefektifkan pencapaian akademik siswa baik kognitif, psikomotorik, ataupun afektif. Hasil dari proses belajar tersebut tercermin dalam prestasi belajarnya. Namun untuk mendapatkan prestasi yang memuaskan dibutuhkan proses belajar. Proses belajar diartikan sebagai proses perubahan tingkah laku individu melalui interaksi dengan lingkungannya (Hamalik, 2009:37). Proses model pembelajaran pemaknaan ini diharapkan dapat mengembangkan karakter, berguna, jujur, bermoral, disiplin, tulus pada diri sendiri, tanggung jawab, mengintegrasikan tujuan belajar dalam tujuan hidupnya, dan memanfaatkan peluang.

Salah satu usaha yang dapat dilakukan dalam mengintegrasikan pengembangan karakter kepada siswa yaitu pemodelan dengan meperhatikan secara menyeluruh hal terkait pengembangan karakter mulai dari perencanaan sampai tahap evaluasi. 
Kemendiknas (2010:43) mengemukakan bahwa pemodelan adalah proses penampilan suatu contoh agar orang lain berpikir, bekerja, dan belajar. Guru bukan satu-satunya model yang dapat ditiru oleh siswa. Model dapat dirancang dengan melibatkan siswa, memaknai konsep yang dipelajari untuk dijadikan model. Pemodelan dalam pembelajaran dapat menumbuhkan rasa ingin tahu, menghargai orang lain, dan rasa percaya diri. Sehingga hal ini juga menjadi landasan bahwa pembelajaran pemaknaan dapat dijadikan salah satu alternatif dalam mengembangkan karakter siswa.

Pegembangan karakter menurut Kementrian Pendidikan Nasional (dalam Samani, 2012:19) yang berlangsung dalam pendidikan formal yaitu melalui pembelajaran di kelas, kegiatan kurikuler, penciptaan budaya satuan pendidikan, dan pembiasaan. Maka pengembangan karakter salah satunya dapat dilakukan dalam pembelajaran. Habibi (2010:31) menyatakan bahwa pembelajaran memiliki makna suatu proses kompleks yang memberikan pengalaman belajar kepada siswa sesuai dengan tujuan pembelajaran. Penekanan makna ini utamanya ditujukan pada proses atau halhal yang dilakukan oleh guru dan siswa. Proses interaksi siswa dengan lingkungan belajarnya banyak didapatkan dalam pembelajaran sehingga fokus penelitian ini lebih ditekankan pada proses pembelajaran yang terjadi di kelas. Pengembangan nilai-nilai karakter sosial dapat dikembangkan dengan penugasan kelompok, Lickona (2013:284) menyebutkan bahwa proses pembelajaran kelompok dapat mengembangkan tanggung jawab kelompok terhadap individu dan individu terhadap kelompok. Selain itu, Samani (2012:162) menyebutkan bahwa pembelajaran kelompok yang dikenal dengan kooperatif terbukti merupakan pembelajaran yang efektif bagi bermacam karakteristik dan latar sosial siswa sehingga dapat meningkatkan hasil belajar, mendorong untuk saling menghargai, menjalin persahabatan di antara berbagai kelompok siswa, kerjasama, tanggung jawab individu, dan kelompok.

Penelitian ini dilakukan di MTsN Terate Pandian Sumenep karena menurut pengamatan pada bulan November 2012 karakter siswa MTsN Terate Pandian Sumenep kurang baik. Hal ini dibuktikan dari data Badan Konseling di MTsN Terate Pandian Sumenep bahwa tercatat 1-5 orang siswa terlambat setiap mengikuti upacara bendera, beberapa siswa terlibat kasus menonton video porno, dan hal lainnya, sehingga guru kurang sadar untuk melakukan pembimbingan dan pengarahan pada siswanya agar menjadi pribadi yang baik. Contoh sikap yang kurang diperhatikan guru yaitu keterlambatan siswa dalam mengumpulkan tugas, sikap malas melaksanakan piket kelas, malas mengerjakan tugas, kurang menghargai pendapat teman lainnya pada saat diskusi, bermusuhan antar teman kelas, kurangnya sikap kerjasama dalam kelompok, merokok, perilaku mencontek pada saat ujian atau ulangan, dan tidak mengikuti pelajaran. Selain itu, pembelajaran di sekolah belum pernah menerapkan pembelajaran pemaknaan.

Berdasarkan permasalahan diatas, maka tujuan dalam penelitian ini adalah: 1) untuk mengetahui keterlaksanaan penerapan pembelajaran pemaknaan pada pelajaran IPA kelas VIII MTsN Terate Pandian Sumenep; 2) untuk mengetahui perbedaan antara character building siswa yang mengikuti penerapan model pembelajaran pemaknaan pada pelajaran IPA dengan yang tidak mengikuti di kelas VIII MTsN Terate Pandian Sumenep.

\section{METODE PENELITIAN}

Penelitian ini menggunakan jenis penelitian deskriptif kuantitatif yang 
bertujuan mendeskripsikan secara kuantitatif efektivitas pembelajaran pemaknaan dalam pembelajaran IPA di MTsN Terate Pandian Sumenep. Desain penelitian menggunakan posttest-only two-group randomized experimental design.

Populasi dalam penelitian ini adalah seluruh siswa kelas VIII MTsN Terate Pandian yang terdiri dari enam kelas dengan jumlah siswa 205 orang. Teknik pengambilan sampel menggunakan purposive random sampling. Kelompok kelas kontrol dan kelas eksperimen ditentukan dengan teknik purposive sampling yaitu kelas VIII-A dan VIII-D sebagai kelas eksperimen, serta kelas VIII-C dan VIIIF sebagai kelas kontrol. Kelas tersebut dipilih secara langsung oleh peneliti berdasarkan pertimbangan tertentu yaitu hasil penelitian ini nantinya dapat mewakili populasi, kelas eksperimen dan kontrol diasumsikan homogen, dan didasarkan pada hasil observasi pada bulan November 2012, serta wawancara dengan guru. Sampel dalam setiap kelompok dipilih secara random sampling dengan jumlah sampel acak dan proporsinal yaitu 14-16 orang dalam setiap kelas atau secara keseluruhan sampel dalam penelitian ini adalah 60 orang.

Teknik pengumpulan data yang digunakan dalam penelitian ini adalah dengan cara observasi non partisipatif. Observasi ini digunakan untuk mengukur dan mendapatkan data character building siswa dan penerapan model pembelajaran pemaknaan oleh guru. Observasi keterlaksanaan model pembelajaran pemaknaan dan character building siswa dilakukan oleh dua orang observer pada saat pembelajaran berlangsung.

Instrumen penelitian yang

digunakan adalah sebagai berikut:

1. Lembar observasi character building menggunakan jumlah total dan persentase. Jumlah total diakumulasi untuk mendapatkan data masing- masing karakter siswa sedangkan persentase pengamatan dianalisis dengan cara menghitung banyaknya character building yang muncul dibagi dengan karakter keseluruhan yang diamati dikali 100\% (Munawar dalam Sahriz, 2007) sebanyak 7 item karakter. Data hasil pengamatan charcicter building (CB) siswa dihitung dengan menggunakan rumus sebagai berkut:

$\% C B=\frac{\Sigma C B \text { siswa yang muncul }}{\Sigma \text { toral frekuenst } C B} \times 100 \%$ Item karakter yang cinilai berdasarkan aktivitas yang muncul pada saat pembelajaran adalah sebagai berikut: a) Kepatuhan: menyimak penjelasan guru; b) Inisiatif: mencatat pelajaran; c) Cinta ilmu: membaca; d) Kritis, jujur, dan percaya diri: menanyakan/mengajukan pertanyaan atau pendapat; e) Tanggung jawab, disiplin, dan demokratis: membentuk kelompok dan bekerja sama dengan teman/kerja kelompok; f) Mandiri dan kerja keras: mengerjakan tugas sendiri; g) Menghargai orang lain: mendengarkan pendapat orang lain.

2. Lembar observasi penerapan model pembelajaran pemaknaan menggunakan kriteria penilaian dan bobot pilihan 1-4 sebanyak 20 item aspek yang dinilai. Kotcrlaksanaan pembelajaran dihitung dengan rumus sebagai bcrikut:

$$
\text { skor }=\frac{\sum \text { skor yang diperaleh }}{\sum \text { indikater peailaian }} \times 100 \%
$$

(Arikunto, 2003:182-183)

Hasil penilaian keterlaksanaan pembelajaran diinterpretasikan:

a. Sangat baik (SB): Jika nilai yang diperoleh 0,76-1,00.

b. Baik (B): Jika nilai yang diperoleh $0,56-0,75$.

c. Kurang (K): Jika nilai yang diperoleh $0,26-0,50$.

d. Sangat kurang (KS): Jika nilai yang diperoleh $0,00-0,25$.

Teknik analisis data dalam penelitian ini menggunakan uji beda yaitu uji statistik t-test 2 sampel 
independen pada character building siswa kelas control dan eksperimen. Asumsi yang harus dipenuhi dalam $t$-test sebagai uji statistik parametrik adalah sebagai berikut.

1. Kedua data berdistribusi normal;

2. data berupa skala data interval;

3. data dapat dibandingkan antara satu dan lainnya.

Data yang tidak memenuhi asumsi, maka menggunakan uji statistik non parametrik yaitu uji U-Mann Withney. Langkahlangkah teknik analisis data dalam penelitian ini adalah sebagai berikut:

1. Uji Normalitas

Uji normalitas dilakukan sebagai asumsi dilakukannya uji beda suatu data. Uji normalitas dilakukan menggunakan SPSS-16 pada tes Kolmogorov-Smirnov. Pengambilan keputusan tentang data tersebut mendekati atau merupakan distribusi normal dapat dilihat dari:

a. Nilai signifikan $<0,05$, maka distribusi data tidak normal.

b. Nilai signifikan $>0,05$, maka distribusi data normal.

Apabila data tidak berdistribusi normal maka dilakukan transformasi, kemudian uji normalitas data transform. Jika tetap tidak normal maka uji statistik non parametrik dapat digunakan. Namun apabila data terdistribusi normal maka dilanjutkan pada langkah berikutnya.

2. Uji Homogenitas

Uji homogenitas digunakan untuk menguji kesamaan varians dua populasi. Uji homogenitas variansi dalam penelitian ini menggunakan uji levene test dengan software SPSS-16. Pedoman pengambilan keputusan tentang data dapat dilihat sebagai berikut.

a. Nilai sign. $<0,05$, maka ragam populasi dari kedua sampel adalah tidak homogen.

b. Nilai sign. $>0,05$, maka ragam populasi dari kedua sampel adalah homogen.
3. Uji t-test 2 sampel independen

Uji t 2 sampel independen dalam penelitian ini digunakan untuk menguji hipotesis penelitian dengan menggunakan SPSS-16. Ketentuan hipotesis diterima atau ditolak adalah sebagai berikut.

$\mathrm{H}_{0}$ : tidak ada perbedaan character building siswa yang mengikuti penerapan model pembelajaran pemaknaan pada pelajaran IPA dengan yang tidak mengikuti di kelas VIII MTsN Terate Pandian Sumenep.

$\mathrm{H}_{1}$ : ada perbedaan character building siswa yang mengikuti penerapan model pembelajaran pemaknaan pada pelajaran IPA dengan yang tidak mengikuti di kelas VIII MTsN Terate Pandian Sumenep.

Keputusan menggunakan tabel output t-test pada SPSS-16 dengan taraf signifikansinya 5\% maka dapat diinterpretasikan sebagai berikut.

a. Nilai Sig. atau signifikan $<0,05$, maka tolak $\mathrm{H}_{0}$.

b. Nilai Sig. atau signifikan $>0,05$, maka terima $\mathrm{H}_{0}$.

Jika data tidak berdistribusi normal atau tidak memenuhi asumsi uji statistik parametrik, maka teknik analisis data yang digunakan adalah uji U-Mann Withney. Keputusan menggunakan tabel output U-Mann Withney pada SPSS-16 dengan taraf signifikansi $5 \%$ adalah sebagai berikut.

a. Nilai Sig. atau signifikan $<0,05$, maka tolak $\mathrm{H}_{0}$.

b. Nilai Sig. atau signifikan $>0,05$, maka terima $\mathrm{H}_{0}$.

\section{HASIL DAN PEMBAHASAN}

Hasil Penelitian

1. Keterlaksanaan Pembelajaran Pemaknaan

Keterlaksanaan pembelajaran pemaknaan pada pelajaran IPA kelas VIII 
semester II pada materi pelajaran getaran dan gelombang yang dilaksanakan oleh guru dengan instrumen observasi berskala likert 1-4 dan diambil oleh dua orang observer selama penelitian yaitu $4 \mathrm{x}$ pertemuan adalah sebagai berikut.

Tabel 1. Keterlaksanaan Pembelajaran Pemaknaan

\begin{tabular}{clcc}
\hline No & \multicolumn{1}{c}{ Indikator } & Jumlah (\%) & Kriteria \\
\hline 1 & Mengorientasikan siswa terhadap masalah & 83,85 & Sangat Baik \\
\hline 2 & Merancang proses pemecahan masalah & 88,54 & Sangat Baik \\
\hline 3 & Membimbing penyelidikan & 89,06 & Sangat Baik \\
\hline 4 & Mengkomunikasikan hasil & 76,56 & Sangat Baik \\
\hline 5 & Negosiasi dan konfirmasi & 73,96 & Baik \\
\hline 6 & Pemaknaan & 90,63 & Sangat Baik \\
\hline 7 & Evaluasi dan refleksi & 67,71 & Baik \\
\hline & Persentase Keseluruhan & \multicolumn{2}{c}{$\mathbf{8 1 , 4 7}$} \\
\hline & Kategori & \multicolumn{2}{c}{ Sangat Baik } \\
\hline
\end{tabular}

Sumber: data primer, diolah pada Mei 2013

Berdasarkan tabel 1, keterlaksanaan model pembelajaran pemaknaan keseluruhan memiliki persentase sebesar $81,47 \%$, hal ini dapat dikategorikan sangat baik. Sedangkan untuk keterlaksanaan setiap sintaks pembelajaran yaitu pada sintaks pemaknaan memiliki nilai tertinggi sebesar 90,63\%. Hal ini mengindikasikan bahwa pembelajaran pemaknaan terlaksana dengan sangat baik walaupun pada evaluasi dan refleksi memiliki persentase sebesar $67,71 \%$ atau paling rendah diantara sintaks lainnya.
2. Character building Siswa di MTsN Terate Pandian Sumenep

a. Perbedaan Character Building Siswa Berdasarkan Persentase

Data character building yang ditunjukkan oleh beberapa aktivitas siswa pada pelajaran IPA di kelas ekperimen yang menggunakan model pembelajaran pemaknaan sebagai indikasi karakter yang berkembang dari siswa dengan sampel 30 orang siswa secara kuantitatif ditunjukkan pada Gambar 1.
Keterangan :



$1:$ Kepatuhan

2: Inisiatif

3 : Cinta ilmu

4 : Kritis, jujur dan percaya diri
5 : Tanggungjawab, disiplin, dan demokratis

6 : Mandiri dan kerja keras

7 : Menghargai orang lain

Gambar 1. Diagram Rata-rata Karakter Siswa di Kelas Eksperimen

Berdasarkan Gambar 1, rata-rata setiap karakter yang ditunjukkan melalui aktivitas siswa memiliki nilai tertinggi pada karakter menghargai orang lain dan 
kepatuhan yaitu 7,16 dan 7,08, sedangkan nilai terendah terdapat pada karakter mandiri dan kerja keras yaitu 3,36. Ratarata terendah tersebut tidak jauh beda dengan aktivitas yang menunjukkan karakter tanggung jawab, disiplin, dan demokratis yaitu 3,45 .

Tabel 2. Aktivitas Mengganggu Siswa Saat Pembelajaran Eksperimen

\begin{tabular}{ccc}
$\begin{array}{c}\text { Jumlah } \\
\text { Siswa }\end{array}$ & $\begin{array}{c}\text { Jumlah } \\
\text { Total } \\
\text { Aktivitas }\end{array}$ & $\begin{array}{c}\text { Rata-rata Aktivitas } \\
\text { Mengganggu }\end{array}$ \\
\hline 30 & 55,50 & 1,85 \\
\hline
\end{tabular}

Sumber: data primer, diolah pada Mei 2013

Berdasarkan Tabel 2 rata-rata aktivitas pengganggu pembelajaran di kelas eksperimen adalah 1,85 dengan jumlah total 55,50. Aktivitas yang mengganggu pembelajaran di dalam kelas berdasarkan observasi ditunjukkan dengan berbicara dengan teman (tidak mendengarkan penjelasan guru), tidur dalam kelas, mengerjakan hal yang tidak berkaitan dengan pembelajaran (menulis pelajaran lain), bergurau, dan makan dalam kelas.

Deskripsi data character building siswa yang diindikasikan dari beberapa aktivitas yang muncul pada saat pembelajaran IPA di kelas kontrol yang tidak menggunakan model pembelajaran pemaknaan dengan 30 orang siswa secara kuantitatif dapat ditunjukkan pada Gambar 2.

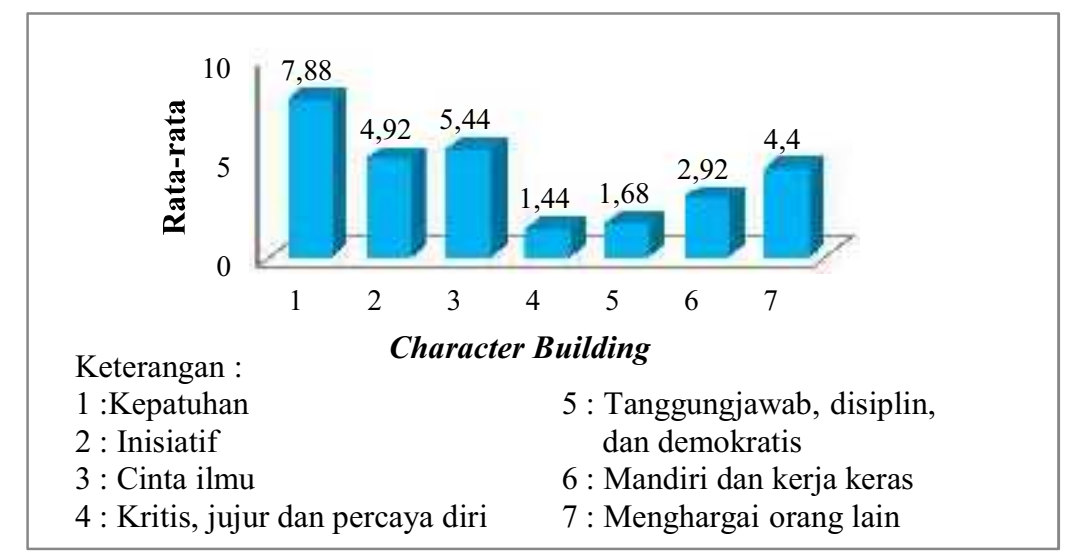

Gambar 2. Diagram Rata-rata Karakter Siswa di Kelas Kontrol

Gambar 2 menunjukkan rata-rata character building siswa di kelas kontrol dengan aktivitas tertinggi yang muncul yaitu menyimak pelajaran yang menunjukkan karakter kepatuhan dan membaca pelajaran yang menunjukkan karakter cinta ilmu yaitu sebesar 7,88 dan 5,44 , sedangkan aktivitas terendah yaitu menanyakan atau mengajukan pendapat dan bekerja kelompok yang menunjukkan karakter kritis, jujur, percaya diri, tanggung jawab, disiplin, dan demokratis.

Tabel 3. Aktivitas Mengganggu Siswa Saat Pembelajaran Kontrol

\begin{tabular}{ccc}
\hline Jumlah & Jumlah & Rata-rata \\
\hline
\end{tabular}

\begin{tabular}{ccc}
\hline Siswa & $\begin{array}{c}\text { Total } \\
\text { Aktivitas }\end{array}$ & $\begin{array}{c}\text { Aktivitas yang } \\
\text { Mengganggu }\end{array}$ \\
\hline 30 & 65,25 & 2,18 \\
\hline
\end{tabular}

Sumber: data primer, diolah pada Mei 2013

Tabel 3 menunjukkan rata-rata aktivitas pengganggu pembelajaran di kelas kontrol yaitu 2,18 dengan jumlah total 65,25. Aktivitas siswa yang mengganggu pembelajaran tidak jauh beda dengan kelas eksperimen seperti berbicara dengan teman dan sebagainya.

Character building siswa secara keseluruhan pada deskripsi statistik di kelas eksperimen ataupun kontrol memiliki beberapa dimensi karakter dari aktivitas yang muncul untuk 
menunjukkan karakter yang dapat dikembangkan dalam pembelajaran. Berdasarkan observasi yang dilakukan, perbandingan persentase setiap karakter yang dikembangkan dalam pembelajaran di kelas kontrol dan kelas eksperimen ditunjukkan dengan data pada Gambar 3.

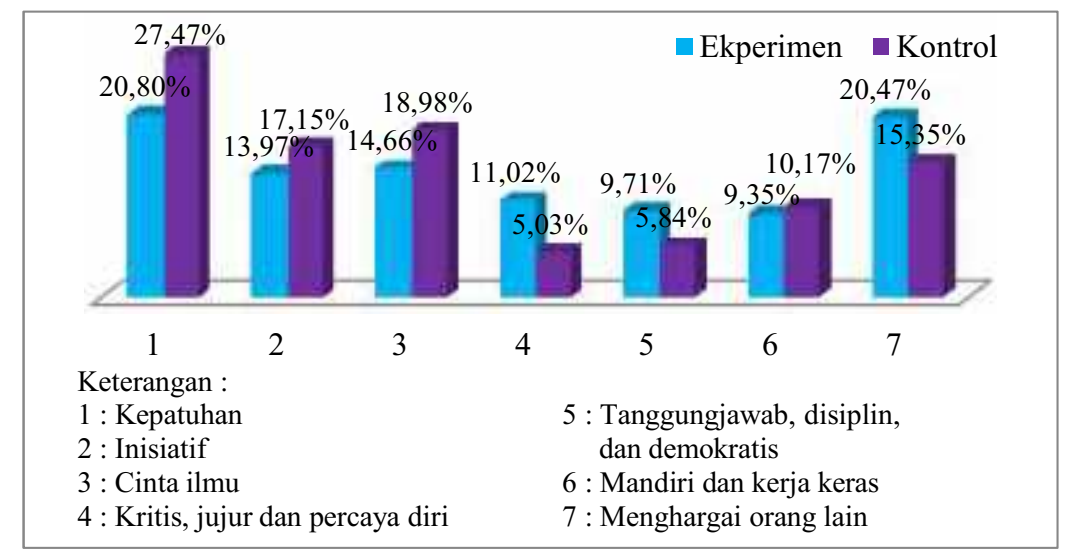

Gambar 3. Perbandingan Character Building Siswa Kelas Eksperimen dan Kontrol

Gambar 3 menunjukkan bahwa karakter yang mengalami peningkatan dari kelas kontrol adalah karakter pribadi meliputi kritis, jujur, dan percaya diri, serta karakter sosial meliputi karakter tanggung jawab, disiplin, demokratis, dan menghargai orang lain. Karakter kepatuhan, inisiatif, cinta ilmu, mandiri, dan kerja keras mengalami penurunan dari kelas kontrol. Selisih persentase peningkatan dan penurunan karakter siswa dari kelas kontrol tersebut dapat dilihat pada Tabel 4.

Tabel 4. Selisih Persentase Peningkatan dan Penurunan Karakter Siswa (dari Kelas Kontrol)

\begin{tabular}{lcc}
\hline \multicolumn{1}{c}{ Karakter } & $\%$ & Ket. \\
\hline Kepatuhan & $6,67 \%$ & Turun \\
\hline Inisiatif & $3,18 \%$ & Turun \\
\hline Cinta ilmu & $4,32 \%$ & Turun \\
\hline $\begin{array}{l}\text { Kritis, jujur, dan } \\
\text { percaya diri }\end{array}$ & $5,99 \%$ & Naik \\
\hline $\begin{array}{l}\text { Tanggung jawab, } \\
\text { disiplin, dan demokratis }\end{array}$ & $3,87 \%$ & Naik \\
\hline Mandiri dan kerja keras & $0,82 \%$ & Turun \\
\hline Menghargai orang lain & $5.12 \%$ & Naik \\
\hline \multicolumn{2}{l}{ Karakter yang meningkat } \\
$\begin{array}{l}\text { Peningkatan karakter yang } \\
\text { dari kelas kontrol berdasarkan }\end{array}$ & Tabel 4.
\end{tabular}

adalah karakter tanggung jawab, disiplin, dan demokratis, sedangkan penurunan karakter tertinggi terjadi pada karakter kepatuhan yang ditunjukkan oleh aktivitas menyimak pelajaran/penjelasan guru.

\section{b. Perbedaan Character Building Siswa Berdasarkan Uji Statistik (T-test)}

Hipotesis yang diajukan dalam penelitian ini yaitu terdapat perbedaan character building siswa kelas yang menggunakan pembelajaran pemaknaan dan pembelajaran non-pemaknaan. Perbedaan character building siswa yang menggunakan pembelajaran pemaknaan dengan non pemaknaan pada mata pelajaran IPA bahasan getaran dan gelombang dapat dianalisis dengan uji beda (uji T) independen di SPSS-16.

Uji $\mathrm{T}$ dapat digunakan apabila memiliki data berbentuk kategorik dan numerik. Data kategorik didapatkan dari kelas yang menerapkan model pembelajaran pemaknaan dan kelas yang tidak menerapkannya, sedangkan data numerik muncul dari skor character building siswa yang diukur melalui hasil observasi.

Langkah awal yang dilakukan dalam $t$-test 2 sampel independen adalah 
uji normalitas untuk mengukur apakah data memiliki distribusi normal sehingga dapat dipakai dalam statistik parametrik (statistik inferensial) dengan menggunakan One-Sample Kolmogorov Smirnov Test. Hasil analisis uji normalitas dan uji beda data kelas kontrol dan eksperimen terlihat pada Tabel 5 .

Tabel 5. Uji Normalitas Data Character

\begin{tabular}{|c|c|c|}
\hline \multicolumn{3}{|c|}{ Building Siswa } \\
\hline Analisis & Eksperimen & Kontrol \\
\hline $\begin{array}{l}\text { Sign. (2-tailed) } \\
\text { Kolmogorov Smirnov }\end{array}$ & .138 & .131 \\
\hline Sign. Levene's Test & .230 & \\
\hline Sign. T-test & .000 & \\
\hline Mean Difference & 6,34 & \\
\hline
\end{tabular}

Tabel 5 menunjukkan bahwa signifikansi uji normalitas data menggunakan kolmogorov smirnov kelas eksperimen adalah $0,138>0,05$. Hal ini dapat diinterpretasikan bahwa data character building di kelas eksperimen berdistribusi normal karena sig. $>0,05$. Signifikansi data kelas kontrol juga menunjukkan sig. $>0,05$ yaitu $0,131>0,05$; sehingga interpretasi dari data character building di kelas kontrol adalah data berdistribusi normal.

Berdasarkan hasil analisis uji normalitas, maka analisis berikutnya yaitu uji homogenitas data menggunakan levene's test dan T-test 2 sampel independen. Data hasil uji homogenitas dengan Levene's test pada tabel 5. menunjukkan nilai sig. 0,230 , jika dibandingkan dengan $\alpha=5 \%$ maka $0,230>0,05$, dapat diinterpretasikan bahwa data tersebut memiliki varian yang homogen. Nilai sig. character building siswa pada output $t$ test menunjukkan angka 0,000 . Hal ini dapat diartikan bahwa sig. $<0,05$ yaitu $0,000<0,05$, sehingga dapat disimpulkan bahwa terdapat perbedaan antara kelas yang menggunakan pembelajaran pemaknaan dengan yang tidak menggunakannya. Output pada baris mean difference untuk character building siswa adalah 6,34. Angka ini berasal dari rata-rata character building kelas ekperimen dikurangi ratarata character building kelas kontrol, sehingga dapat diinterpretasikan bahwa kelas eksperimen character building siswanya lebih baik daripada kelas kontrol sebanyak 6,34 point.

Uji beda dalam penelitian ini juga digunakan untuk menguji perbedaan setiap karakter yang muncul pada saat penelitian. Langkah-langkah dalam uji beda setiap karakter berdasarkan pada asumsi pada uji beda parametrik. Pertama yaitu menguji normalitas data. Hasil uji normalitas data ditunjukkan dalam Tabel 6.

Tabel 6. Uji Normalitas Data Setiap Item Karakter

\begin{tabular}{|c|c|c|}
\hline \multirow{2}{*}{ Karakter } & Eksperimen & Kontrol \\
\hline & \multicolumn{2}{|c|}{ Asymp. Sig. (2-tailed) } \\
\hline Kepatuhan & $.886^{*}$ & $.750 *$ \\
\hline Inisiatif & $.512 *$ & $.211 *$ \\
\hline Cinta Ilmu & $.113 *$ & $.581 *$ \\
\hline $\begin{array}{l}\text { Kritis, jujur, dan } \\
\text { percaya diri }\end{array}$ & $.201 *$ & $.731^{*}$ \\
\hline $\begin{array}{l}\text { Tanggung jawab, } \\
\text { disiplin, dan } \\
\text { demokratis }\end{array}$ & $.199 *$ & $.021 *$ \\
\hline $\begin{array}{l}\text { Mandiri dan kerja } \\
\text { keras }\end{array}$ & $.333 *$ & $.551 *$ \\
\hline $\begin{array}{l}\text { Menghargai orang } \\
\text { lain }\end{array}$ & $.591 *$ & $.553 *$ \\
\hline $\begin{array}{l}\text { * Uji Normalitas } \\
\text { Smirnov Test }\end{array}$ & One-Sample & Kolme \\
\hline
\end{tabular}

Tabel 6 menunjukkan bahwa uji normalitas data setiap item karakter memiliki nilai sig. $>0,05$, kecuali karakter tanggung jawab, disiplin, dan demokratis di kelas kontrol. Penarikan kesimpulan didasarkan pada nilai sig. $<0,05$ maka data berdistribusi tidak normal, sedangkan apabila sig. $>0,05$, maka data berdistribusi normal. Nilai signifikansi item karakter diatas 0,05 yang terdapat pada Tabel 6 dapat diinterpretasikan bahwa datanya berdistribusi normal, sedangkan karakter tanggung jawab, disiplin, dan demokratis di kelas kontrol mempunyai nilai sig. $<0,05$ dapat 
diinterpretasikan bahwa datanya tidak berdistribusi normal.

Karakter yang memiliki data berdistribusi normal dilanjutkan dengan uji homogenitas dan uji $\mathrm{T}$, sedangkan yang tidak normal dilanjutkan dengan transformasi data tidak normal kemudian dilakukan uji normalitas kembali, jika data normal dilanjutkan dengan uji $\mathrm{T}$ dan jika data tidak normal dilanjutkan dengan uji U-Mann Withney. Data hasil analisis secara ringkas disajikan dalam beberapa dimensi karakter pada Tabel 7.

Tabel 7. Uji Beda Karakter Siswa

\begin{tabular}{llrrrrl}
\hline \multirow{2}{*}{ No } & \multirow{2}{*}{ Karakter } & \multicolumn{2}{c}{ Uji Homogen } & \multicolumn{2}{c}{ Uji Beda } & \multirow{2}{*}{ Keputusan } \\
\cline { 2 - 5 } & & Uji & Sign. & Uji & Sign. & \\
\hline $\mathbf{1}$ & Kepatuhan & Levene's Test & 0,077 & Uji T & 0,047 & Tolak H0 \\
\hline $\mathbf{2}$ & Inisiatif & Levene's Test & 0,656 & Uji T & 0,941 & Terima H0 \\
\hline $\mathbf{3}$ & Cinta Ilmu & Levene's Test & 0,000 & Uji T & 0,280 & Terima H0 \\
\hline $\mathbf{4}$ & Kritis, jujur, dan percaya diri & Levene's Test & 0,000 & Uji T & 0,000 & Tolak H0 \\
\hline $\mathbf{5}$ & Tanggung jawab, disiplin, dan demokratis & Levene's Test & - & Uji U & 0,000 & Tolak H0 \\
\hline $\mathbf{6}$ & Mandiri dan kerja keras & Levene's Test & 0,276 & Uji T & 0,094 & Terima H0 \\
\hline $\mathbf{7}$ & Menghargai orang lain & Levene's Test & 0,626 & Uji T & 0,000 & Tolak H0 \\
\hline
\end{tabular}

Tabel 7 menunjukkan bahwa karakter yang memiliki perbedaan antara kelas kontrol dan eksperimen adalah karakter kepatuhan, kritis, jujur, dan percaya diri, tanggung jawab, disiplin, dan demokratis serta menghargai orang lain yang selanjutnya menjadi landasan hasil penelitian ini.

Berdasarkan analisis perbandingan karakter yang dikembangkan dalam pembelajaran, maka ringkasan data gabungan perbandingan secara statistik deskriptif dan uji t terlihat pada Tabel 8 .

Tabel 8. Perbandingan Persentase dan Uji Statistik Item Karakter Kelas Eksperimen (E) dan Kontrol (K)

\begin{tabular}{llrrrr}
\hline \multirow{2}{*}{ No } & & \multirow{2}{*}{ Karakter } & \multicolumn{4}{c}{ Perbandingan } \\
\cline { 3 - 6 } & & $\mathbf{\%}$ & Selisih \% & Uji Statistik & Analisa \\
\hline $\mathbf{1}$ & Kepatuhan & $\mathrm{E}<\mathrm{K}$ & $6,67 \%$ & Ada beda & $\sqrt{ }$ \\
\hline $\mathbf{2}$ & Inisiatif & $\mathrm{E}<\mathrm{K}$ & $\mathbf{3 , 1 8 \%}$ & Tidak ada beda & - \\
\hline $\mathbf{3}$ & Einta Ilmu & $\mathrm{E}<\mathrm{K}$ & $4,32 \%$ & Tidak ada beda & - \\
\hline $\mathbf{4}$ & Kritis, jujur, dan percaya diri & $\mathrm{E}>\mathrm{K}$ & $5,99 \%$ & Ada beda & $\sqrt{ }$ \\
\hline $\mathbf{5}$ & Tanggug jawab, disiplin, dan demokratis & $\mathrm{E}>\mathrm{K}$ & $3,87 \%$ & Ada beda & $\sqrt{ }$ \\
\hline $\mathbf{6}$ & Mandiri dan kerja keras & $\mathrm{E}<\mathrm{K}$ & $0,82 \%$ & Tidak ada beda & - \\
\hline $\mathbf{7}$ & Menghargai orang lain & $\mathrm{E}>\mathrm{K}$ & $5,12 \%$ & Ada beda & $\sqrt{ }$ \\
\hline
\end{tabular}

Ket : $\mathrm{E}=$ eksperimen, $\mathrm{K}=$ kontrol

Sumber: data primer, diolah pada Juni 2013

Tabel 8 menunjukkan bahwa fokus karakter yang dikembangkan dari pembelajaran pemaknaan berdasarkan hasil analisis data adalah karakter kepatuhan yang mengalami penurunan dari kelas control, serta karakter kritis, jujur, percaya diri, tanggung jawab, disiplin, demokratis, dan menghargai orang lain yang mengalami peningkatan dari kelas kontrol. Sehingga berdasarkan hasil tersebut karakter yang meningkat terdapat pada karakter sosial yang hubungannya dengan sosial atau orang lain dan karakter pribadi siswa.

\section{Pembahasan}

\section{Keterlaksanaan Pembelajaran Pemaknaan \\ Keterlaksaan pembelajaran pemaknaan dikonstruk dan diadaptasi}


dari sintaks model pembelajaran pemaknaan yang dikembangkan oleh Muslimin Ibrahim kemudian dikembangkan lagi oleh peneliti dengan membagi menjadi 20 indikator keterlaksanaan pembelajaran pemaknaan dari dimensi sintaks pembelajaran. Beberapa hal dapat diketahui dari hasil observasi oleh 2 orang observer selama penelitian yaitu persentase sintaks pemaknaan memiliki nilai tertinggi sebesar 90,63\%. Hal ini mengindikasikan bahwa sintaks pembelajaran pada pemaknaan terlaksana dengan sangat baik. Sintaks evaluasi dan refleksi memiliki persentase terendah sebesar $67,71 \%$. Peneliti mengasumsikan hal ini dikarenakan banyak siswa yang kesulitan dalam melakukan praktikum/kerja kelompok sehingga waktu yang digunakan cukup lama, selain itu adanya langkah mengkomunikasikan hasil penyelidikan juga menyebabkan waktu pembelajaran berlangsung lama, sehingga secara keseluruhan pengelolaan waktu pembelajaran menjadi kurang efisien yang mengakibatkan pada saat evaluasi dan refleksi sebagai langkah terakhir dari model pembelajaran pemaknaan menjadi lebih rendah keterlaksanaan sintaks yang lainnya.

Berdasarkan indikator yang digunakan untuk mengukur keterlaksanaan pembelajaran pemaknaan secara keseluruhan model pembelajaran pemaknaan pada pelajaran IPA dapat dilaksanakan dengan sangat baik, dilihat dari hasil observasi keterlaksanaan model pembelajaran yang mencapai 0,8147 yaitu $81,47 \%$ dengan kategori sangat baik.

Proses pembelajaran pemaknaan yang berlangsung sudah sangat baik. Esensi dari pembelajaran pemaknaan yaitu memaknai gejala atau peristiwa yang terdapat dalam substansi materi pelajaran dan dikaitkan dengan aspek budi pekerti tersampaikan dengan baik. Guru tentunya sudah melaksanakan pembelajaran pemaknaan dengan baik sesuai dengan sintaks yang dikembangkan oleh Ibrahim Muslimin (2008:21-24) yaitu sebagai berikut.

a. Mengorientasikan Siswa terhadap Permasalahan

Sintaks ini mengarahkan siswa pada kegiatan yang membawa siswa pada masalah yang akan dipecahkan dalam proses pembelajaran. Tahapan ini berfungsi untuk menyiapkan dan menarik perhatian siswa serta meningkatkan motivasi siswa. Tahapan ini dilakukan dengan demonstrasi dan memberi pertanyaan kepada siswa (mengarahkan siswa dalam memecahkan masalah yang didemonstrasikan, berpikir kritis, logis, dan jujur).

b. Merancang Proses Pemecahan Masalah

Tahapan ini dilakukan dengan tanya jawab antara guru dan siswa yang bertujuan menemukan cara terbaik yang dapat dilakukan untuk memecahkan masalah. Penelitian ini mengarahkan sintaks merancang proses pemecahan masalah dengan membagi siswa pada beberapa kelompok untuk kemudian mendiskusikan rancangan pemecahan masalah yang diarahkan oleh guru untuk kemudian dilaporkan sebagai bahan materi untuk pertemuan selanjutnya.

c. Membimbing Penyelidikan

Tahapan ini guru memberikan bimbingan kepada siswa baik secara individu maupun kelompok untuk melakukan rencana yang telah disepakati, sehingga mereka dapat menemukan jawaban masalah atau pertanyaannya. Kegiatan penyelidikan dalam penelitian ini yaitu eksperimen yang hasil kegiatan akhirnya adalah mengolah data yang didapatkan dari eksperimen untuk kemudian menemukan jawaban dari permasalahan yang ingin dipecahkan. 
d. Mengkomunikasikan Hasil

Setelah siswa melaksanakan kegiatan dan menyimpulkan hasilnya, siswa diminta untuk mengkomunikasikan temuannya kepada siswa lain. Oleh karena itu, pada tahapan mengkomunikasikan hasil, dalam penelitian ini dilaksanakan dalam bentuk presentasi kelas dan menyusun laporan kegiatan. Inti dari tahapan ini adalah siswa lain dapat memperoleh informasi mengenai apa yang ditemukan oleh siswa dan dapat berkontribusi untuk mengkritisi hasil kerja kelompok yang lain.

e. Negosiasi dan Konfirmasi

Pada tahapan ini guru memberikan balikan terhadap apa-apa yang telah disampaikan oleh siswa pada tahapan sebelumnya. Balikan yang diberikan dapat merupakan penguatan, pembetulan, atau penyempurnaan informasi yang disajikan oleh siswa atau menambah informasi yang kurang. Guru juga mengecek pemahaman siswa dengan memberikan pertanyaan kepada siswa terkait materi yang dipelajari.

f. Pemaknaan

Ciri inovasi dari model ini adalah adanya sintaks pemaknaan gejala atau peristiwa yang terdapat dalam substansi materi pelajaran dikaitkan dengan aspek-aspek budi pekerti, norma-norma yang harus ditaati. Selain itu, pemaknaan dapat menggunakan gejala dan temuan dari siswa untuk menanamkan prinsip kebaikan, moral, dan akhlakul karimah. Dalam penelitian ini, pemaknaan dilakukan secara variasi sesuai dengan RPP yang telah disusun sebelumnya.

g. Evaluasi dan Refleksi

Tahap ini bertujuan untuk mengetahui seberapa jauh siswa telah mencapai tujuan yang tela direncanakan, memperkuat retensi siswa, menemukan hal-hal yang sudah baik yang perlu dipertahankan atau menemukan hal-hal yang masih perlu ditingkatkan. Evaluasi diberikan dengan tes lisan, tertulis, dan unjuk kerja. Sedangkan refleksi dilakukan melalui diskusi. Siswa diminta idenya mengenai hal-hal apa yang sudah baik dan belum baik.

Pembelajaran pemaknaan dalam penelitian ini juga meminimalisir adanya teacher center dalam pembelajaran, aktivitas yang dilakukan disesuaikan dengan langkah pembelajaran pemaknaan. Selaras dengan prinsip dari pembelajaran pemaknaan ini (Ibrahim, 2008:9) yaitu mengorientasikan siswa pada situasi yang bermakna dan kontekstual dengan menjadikannya sebagai subjek pembelajar yang aktif dalam membangun pengetahuan dari pengalaman yang diberikan pada proses pembelajaran.

\section{Character Building Siswa di MTsN Terate Pandian Sumenep}

Pembelajaran pemaknaan dalam teorinya dikemukakan bahwa pembelajaran tersebut mengutamakan penekanan pada aspek afektif siswa yang selama ini hanya menjadi efek penyerta dalam proses pembelajaran. Tentunya implementasi pembelajaran pemaknaan akan dapat mengembangkan sikap sebagai pondasi siswa dalam pengembangan karakter yang dimiliki untuk menjadi manusia yang baik dan berkarakter. Terkait dengan hasil penelitian ini menunjukkan bahwa terdapat perbedaan character building siswa pada kelas yang menggunakan pembelajaran pemaknaan dengan yang tidak menggunakannya. Pada analisis data uji $T$, signifikansi menunjukkan angka lebih kecil dari 0,05, sehingga dapat disimpulkan ada perbedaan kelas kontrol yang tidak menggunakan pembelajaran pemaknaan dan eksperimen yang menggunakan pembelajaran pemaknaan.

Perbedaan hasil analisis ini memberikan gambaran bahwa prinsip 
dasar, tujuan pembelajaran pemaknaan baik secara umum ataupun secara khusus serta beberapa asumsi dasar dalam implementasi pembelajaran terbukti dapat mengembangkan karakter siswa dengan aktivitas-aktivitas yang dilakukan dalam proses kegiatan belajar mengajar dengan model pembelajaran pemaknaan. Hal ini terlihat bahwa dari beberapa indikator yang ditetapkan dalam mengukur keterlaksanaan proses pembelajaran pemaknaan berjalan dengan sangat baik.

Besar perbedaan rata-rata character building siswa kelas eksperimen dan kelas kontrol dari hasil penelitian dan analisis data adalah 6,34. Selisih perbedaan rata-rata yang didapatkan diinterpretasikan bahwa rata-rata kelas kontrol mengalami kenaikan sebesar 6,34 pada kelas eksperimen, dalam artian aktivitas kelas eksperimen lebih banyak 6,34 dari kelas kontrol. Berdasarkan nilai perbedaan rata-rata character building yang didapatkan, maka kelas yang menggunakan pembelajaran pemaknaan memiliki pengembangan karakter yang lebih tinggi daripada kelas yang tidak menggunakan pembelajaran pemaknaan.

Menurut asumsi peneliti selisih angka perbedaan rata-rata tersebut cukup besar, hal ini terjadi karena pada pembelajaran pemaknaan terdapat aktivitas mulai dari praktik dan pemaknaan, sedangkan pada kelas kontrol siswa juga melakukan praktik namun kurang disertai pemaknaan, dengan kata lain peningkatan karakter pada kelas eksperimen merupakan akibat dari pemaknaan substansi materi ataupun kegiatan ilmiah yang dihubungkan dengan perilaku baik atau nilai-nilai karakter untuk dijadikan model dan diinternalisasi dalam diri siswa itu sendiri.

Sesuai dengan landasan teori dari pembelajaran pemaknaan yaitu teori modelling yang dikembangkan oleh Albert Bandura. Ibrahim (2008:19) menyebutkan implementasi teori modelling di dalam model pembelajaran pemaknaan adalah gejala IPA yang terjadi di sekitar siswa dimaknai atau diberi arti dengan jalan dikaitkan dengan berbagai norma perilaku baik, budi pekerti, dan akhlakul karimah yang dapat menjadi model atau contoh yang dapat ditiru oleh siswa. Pendapat tersebut didukung oleh Kemendiknas (2010:43) yang mengemukakan bahwa pemodelan adalah proses penampilan suatu contoh agar orang lain berpikir, bekerja, dan belajar. Guru bukan satu-satunya model yang dapat ditiru oleh siswa. Model dapat dirancang dengan melibatkan siswa ataupun memaknai dari konsep yang dipelajari untuk dijadikan model. Pemodelan dalam pembelajaran antara lain dapat menumbuhkan rasa ingin tahu, menghargai orang lain, dan rasa percaya diri. Namun peneliti berasumsi bahwa menginternalisasi nilai-nilai moral kepada siswa tidak dapat diukur dengan beberapa pertemuan yang dilakukan dalam penelitian ini. Oleh karena itu beberapa aktivitas yang dikembangkan dalam pembelajaran pemaknaan yaitu aktivitas yang dilakukan siswa juga dapat mengindikasikan peningkatan karakter yang dimiliki siswa. Hal ini selaras dengan landasan model pembelajaran pemaknaan yaitu discovery learning yang mengarahkan pembelajaran pemaknaan pada kegiatan ilmiah yang nantinya dari kegiatan tersebut selain mendapatkan keuntungan dari belajar penemuan dalam kegiatan ilmiah itu sendiri juga dapat mengkonstruksi nilai-nilai moral yang terkandung dalam kegiatan yang dilakukan dan konsep yang dipelajari. Landasan tersebut didukung juga

oleh Habibi (2010:114) yang mengemukakan keuntungan belajar penemuan adalah pengetahuan yang diperoleh dapat bertahan lama, dapat meningkatkan penalaran dan kemampuan berfikir karena siswa diarakan untuk menganalisis dalam memecahkan permasalahan, belajar penemuan juga dapat membangkitkan keingintahuan 
siswa, motivasi untuk bekerja sampai mereka menemukan jawaban dari permasalahan yang dihadapi. Berdasarkan keuntungan yang didapatkan dari kegiatan ilmiah yang dilakukan dalam pembelajaran pemaknaan tentunya mendukung keterlaksanaan pembelajaran pemaknaan dapat meningkatkan karakter yang dimiliki oleh siswa dengan aktivitas yang dilakukan untuk menunjukkan karakter yang dikembangkan.

Peningkatan karakter tersebut juga dapat diasumsikan karena lingkungan belajar yang diciptakan oleh guru lebih banyak mengorientasikan pada kegiatan yang berpusat kepada siswa yaitu membentuk kelompok, berdiskusi, mengemukakan pendapat dan mengkomunikasikan hasil dari penyelidikan, sesuai dengan Ibrahim (2008:37) yang menyatakan bahwa lingkungan belajar yang harus diciptakan dalam pembelajaran pemaknaan yaitu tidak kaku, siswa diberi kebebasan untuk bergerak, membentuk kelompok, berdiskusi, menyampaikan pendapat secara bebas. Lingkungan belajar yang terjadi dalam penelitian ini memberikan gambaran bahwa mengarahkan pada aktivitas-aktivitas yang dapat mengembangkan karakter tertentu dalam diri siswa dapat memberikan perbedaan yang signifikan dalam penerapannya dan memiliki selisih beda yang cukup baik dalam pelaksanaannya.

Secara kuantitatif beberapa character building siswa dapat meningkat dengan penerapan pembelajaran pemaknaan. Hasil pengujian dari setiap karakter siswa yang mengikuti kelas pembelajaran pemaknaan dengan yang tidak mengikuti juga dapat dilihat berdasarkan hasil analisis yang didapatkan dari persentasepersentase dan uji statistik yang disajikan pada hasil penelitian. Karakter-karakter sosial yaitu karakter tanggung jawab, disiplin, demokratis, dan menghargai orang lain mengalami peningkatan. Peningkatan dari karakter yang ditunjukkan dengan aktivitas berkelompok dan kerjasama yaitu karakter tanggung jawab, disiplin, dan demokratis mengalami peningkatan yang cukup rendah daripada karakter yang lainnya sebesar $3,67 \%$ sedangkan karakter menghargai orang lain meningkat sebesar $5,12 \%$. Karakter pribadi siswa juga mengalami peningkatan yang cukup tinggi pada karakter kritis, jujur, dan percaya diri yang ditunjukkan dengan aktivitas mengajukan pendapat dan pertanyaan dengan santun sebesar 5,99\%.

Secara keseluruhan selaras dengan tujuan model pembelajaran pemaknaan yang dikemukakan dalam bukunya "Model Pembelajaran Inovatif IPA melalui Pemaknaan" yang dikarang oleh Ibrahim Muslimin disebutkan bahwa tujuan khusus model pembelajaran pemaknaan yaitu kecakapan pengembangan hidup, efektivitas capaian akademik yang ditekankan pada ranah afektif namun tidak mengenyampingkan pencapaian ranah hasil belajar yang lain.

Tujuan khusus pembelajaran pemaknaan tersebut juga didukung dengan proses pembelajaran IPA di SMP/MTs yang tentunya lebih menekankan pada pemberian pengalaman belajar secara langsung melalui penggunaan dan pengembangan proses dan sikap ilmiah (Habibi, 2010:68). Hal tersebut dapat menanamkan sikap-sikap positif yang mengarah pada pembentukan karakter diri yang kuat. Pembelajaran yang dilaksanakan dengan sungguhsungguh akan memberikan sumbangan berharga bagi siswa dalam mempersiapkan dirinya menghadapi kehidupan nyata di masyarakat. Unsurunsur kedisiplinan, kecermatan, ketekunan, ketelitian, dan kejujuran misalnya dalam melakukan kegiatan observasi dan pengukuran secara bertahap akan membentuk karakter siswa.

Peningkatan pada karakter sosial siswa ataupun beberapa karakter pribadi 
siswa juga sesuai dengan prinsip dari pembelajaran pemaknaan itu sendiri yaitu prinsip berpusat pada siswa, pengalaman belajar yang diberikan berorientasi pada siswa sebagai subjek pembelajar, selain itu peran guru dalam pembelajaran pemaknaan bersifat scaffolding, dalam teori belajarnya Vigotsky proses tersebut dapat diterapkan dengan jalan berinteraksi dan membimbing siswa untuk kemudian diarahkan agar siswa mampu mencapai kemampuan potensialnya.

Karakter kepatuhan yang ditunjukkan dengan aktivitas menyimak pelajaran guru mengalami penurunan pada pembelajaran pemaknaan, namun hal ini tidak menjadi permasalahan yang cukup serius karena justru hal tersebut baik untuk siswa dalam mengurangi individualisme siswa SMP yang sesuai dengan taraf perkembangannya merupakan problema yang memerlukan bimbingan dan arahan dalam pembelajaran. Penurunan karakter kepatuhan yang ditunjukkan dengan aktivitas menyimak penjelasan dari guru mengindikasikan bahwa pembelajaran pemaknaan yang berlangsung meminimalisir adanya teacher center yang memposisikan siswa sebagai objek pembelajaran. Hal ini memberikan gambaran yang jelas bahwa pembelajaran pemaknaan dapat diterapkan oleh guru untuk mengembangkan karakter siswa dalam proses kegiatan belajar mengajar. Tentunya perlu diperhatikan bahwa peningkatan dan penurunan karakter siswa juga dapat menjadi buruk ketika pihak sekolah sudah merasa puas dengan apa yang dicapai dengan pembelajaran pemaknaan. Karakter merupakan sifat yang dapat terus berubah, jadi bukan hal yang baik untuk merasa puas dengan pencapaian tersebut, karena banyak faktor yang bisa menjadi ancaman bagi kemerosotan karakter yang dikembangkan.

\section{PENUTUP}

\section{Simpulan}

Penelitian ini dapat disimpulkan:

1. Pembelajaran pemaknaan pada pelajaran IPA terlaksana sangat baik, persentase dimensi keterlaksanaan pembelajaran pemaknaan yaitu tertinggi terdapat pada sintaks pemaknaan dan terendah terdapat pada sintaks evaluasi dan refleksi.

2. Terdapat perbedaan character building siswa antara kelas yang menggunakan model pembelajaran pemaknaan dengan kelas yang tidak menggunakan model pembelajaran pemaknaan.

4. Karakter siswa yang memiliki perbedaan antara kelas kontrol dan eksperimen yaitu karakter kepatuhan yang menurun sebesar $6,67 \%$ dari kelas kontrol, karakter kritis, jujur, dan percaya diri meningkat 5,99\%, karakter tanggung jawab, disiplin, dan demokratis meningkat $3,87 \%$, dan karakter menghargai orang lain meningkat sebesar $5,12 \%$ dari kelas kontrol.

\section{Keterbatasan Penelitian}

Keterbatasan dalam penelitian ini adalah sebagai berikut.

1. Model pembelajaran pemaknaan dalam penelitian ini hanya diterapkan pada materi pelajaran IPA kelas VIII semester II tentang getaran dan gelombang.

2. Penelitian ini hanya memiliki satu faktor penentu character building sebagai variabel dalam metode kuantitatifnya yaitu pembelajaran pemaknaan.

3. Penelitian ini hanya menggunakan instrumen observasi untuk mengukur character building siswa

4. Peneliti hanya meminimalisir perbedaan persepsi observer dengan menggunakan silang pengamatan pada siswa dengan pola pembelajaran yang sama. 


\section{Rekomendasi}

Berdasarkan hasil penelitian dan menindaklanjuti keterbatasanketerbatasan dalam penelitian ini maka rekomendasi yang dapat peneliti berikan sebagai berikut.

1. Pembelajaran pemaknaan dapat dipakai oleh guru di sekolah sebagai salah satu model pembelajaran yang dapat digunakan untuk meningkatkan character building siswa.

2. Untuk menguji konsistensi hasil penelitian maka penelitian yang akan datang sebaiknya menggunakan teknik analisis yang berbeda, misalnya SEM.

3. Penambahan variabel-variabel lain yang diduga akan berdampak pada peningkatan karakter siswa.

4. Peneliti lain yang tertarik pada topik yang sama lebih memperhatikan: a) reliabilitas antar observer dalam penelitian, b) indikator character building dikoreksi ulang dengan memperhatikan subtansi dari nilainilai karakter yang dikembangkan, dan c) tujuan di silabus/RPP diselaraskan dengan tujuan penelitian.

\section{DAFTAR PUSTAKA}

Arikunto, Suharsimi. 2003. Dasar-dasar Evaluasi Pendidikan. Jakarta: PT. Bumi Aksara.

Habibi. 2010. Pembelajaran IPA I. Sumenep: Unija Press.

Hamalik, Oemar. 2009. Kurikulum dan Pembelajaran. Jakarta: Bumi Aksara.

Ibrahim, Muslimin. 2008. Model Pembelajaran Inovatif IPA melalui Pemaknaan. Surabaya: Depdiknas Balitbang Puslicjaknov.

Kemendiknas. 2010. Panduan Pendidikan Karakter di Sekolah Menengah. Jakarta: Direktorat Pembinaan SMP.

Kesuma, Dharma; Triana, Cepi; Permana, Johar. 2011. Pendidikan Karakter: Kajian Teori dan Praktik di Sekolah. Bandung: PT. Remaja Rosdakarya.

Lickona, Thomas. 2013. Educating for Character: Mendidik untuk Membentuk Karakter (Bagaimana Sekolah dapat Mengajarkan Sikap Hormat dan Tanggung Jawab). Jakarta: PT. Bumi Aksara.

Sahriz, Indry Merlyana. 2007. Penerapan Model Pembelajaran Kooperatif dengan Pendekatan Struktural Tipe NHT pada Mata Pelajaran Teknik Bangunan Siswa Kelas 2 SMKN I Kaliange Sumenep. Surabaya: Program Pascasarjana Universitas Negeri Surabaya.

Samani, Muchlas; Hariyanto. 2012. Konsep dan Model Pendidikan Karakter. Bandung: PT. Remaja Rosdakarya.

Sardiman. 2011. Interaksi dan Motivasi Belajar Mengajar. Jakarta: PT. RajaGrafindo Persada.

Sugiyono. 2012. Metode Penelitian Kuantitatif, Kualitatif, dan $R \& D$. Bandung: Alfabeta. 
Jurnal Lentera Sains (Lensa)

60 Jurnal Lensa, Volume 6 Jilid I Mei 2016 